\title{
STUDIES ON THE RENAL CONCENTRATING MECHANISM. II. EFFECT OF SMALL ACUTE CHANGES IN SOLUTE EXCRETION *
}

\author{
By LAWRENCE G. RAISZ $\dagger$ AND ROBERT L. SCHEER
}

(From the Medical and Radioisotope Services, Veterans Administration Hospital, and Department of Medicine, State University of New York Upstate Medical Center, Syracuse, $N . Y$.)

(Submitted for publication June 6, 1958; accepted August 13, 1958)

The renal concentrating mechanism is considered to be limited by a maximal urine osmolal concentration or a maximal osmotic urine/plasma $(\mathrm{U} / \mathrm{P})$ ratio at low rates of solute excretion (1). When solute excretion is increased by the administration of large osmotic loads to hydropenic subjects urine osmolality decreases $(2-4)$. This decrease has recently been ascribed to the limitation imposed by the existence of a maximal rate of net water reabsorption (termed $\mathrm{T}_{\mathrm{m}}{ }^{\mathrm{c}} \mathrm{H}_{2} \mathrm{O}$ ) at high rates of solute excretion and urine flow $(5-7)$. When no osmotic load is given, solute excretion is low in hydropenic subjects so that the net rate of water reabsorption is much below its maximum. Under these circumstances the existence of a constant maximal "osmotic ceiling" independent of small changes in solute excretion and urine flow has been postulated ( 1 , 7 ), but such a limit has not yet been clearly demonstrated experimentally. The present study was therefore undertaken to assess the effects of small, acute changes in solute excretion on the osmotic $\mathrm{U} / \mathrm{P}$ ratio observed in hydropenic normal men. Osmotic U/P ratio was not constant but tended to vary inversely with the concurrent rate of solute excretion.

\section{METHODS}

The subjects were four paid volunteer male medical students who were selected for their ability to void small volumes of urine so that catheterization could be avoided. ${ }^{1}$

* Presented before the Eastern Section Meeting of the American Federation for Clinical Research, New Haven, Conn., Dec. 6, 1957.

$\dagger$ Veterans Administration Clinical Investigator.

1 Originally five subjects were selected by a "bladder emptying test." In this test the subjects voided at intervals of 30 minutes in the resting hydropenic state. The subject was considered acceptable if the creatinine clearance did not vary by more than \pm 10 per cent of
On the day prior to the experiment subjects took no fluids after lunch and had a standard dry supper consisting of toast, meat, cheese, jelly, butter and cake. Experiments were begun at 6:00 to 7:00 a.m. the following morning. The subjects remained recumbent except to void or exercise. Urine samples were obtained at intervals of 30 minutes and blood samples approximately every two hours. The procedures described below were begun at $8: 00$ or $8: 30$ a.m. after three to four preliminary urine samples had been obtained. All experiments were performed from November to March except the urea series which was conducted in May. The following experiments were performed:

1. Resting state. Each subject remained recumbent for five to six hours.

2. Light exercise. Two subjects rode a stationary bicycle for one-half hour at 14 miles per hour against minimal resistance.

3. Venesection. In three subjects, 500 to $600 \mathrm{ml}$. of whole blood was removed in four to 20 minutes.

4. Mannitol infusion. Each subject received an infusion of 5 or 8 per cent mannitol in isotonic $\mathrm{NaCl}$ solution at $1 \mathrm{ml}$. per minute for two hours and at $2 \mathrm{ml}$. per minute for the next two hours.

5. Urea ingestion. Each subject ingested four doses of urea $(25 \mathrm{Gm}$. per $100 \mathrm{ml}$. dissolved in orange juice) at intervals of one hour. The first two doses were $5 \mathrm{Gm}$. and the next two were $10 \mathrm{Gm}$. of urea.

Chemical methods. Creatinine was determined by the Jaffe reaction (8) using adsorption with Lloyd's reagent for the serum (9). Urea was determined by the method of Van Slyke and Cullen (10). Mannitol was determined by a chromotropic acid method (11). Sodium and potassium were determined with an internal standard flame photometer. Osmolality was measured with a Fiske freezing-point osmometer. Duplicate determinations of osmolality agreed within one per cent.

Calculations. Data on urine concentrating ability are presented in terms of the osmotic $U / P$ ratio, and data on

the mean in six periods. Subsequently, one subject showed considerable variation in creatinine clearances and his data were discarded. In 72 preliminary periods of 21 experiments on the four remaining subjects, the average deviation of the creatinine clearance from the day's mean was \pm 6 per cent. 
LAWRENCE G. RAISZ AND ROBERT L. SCHEER

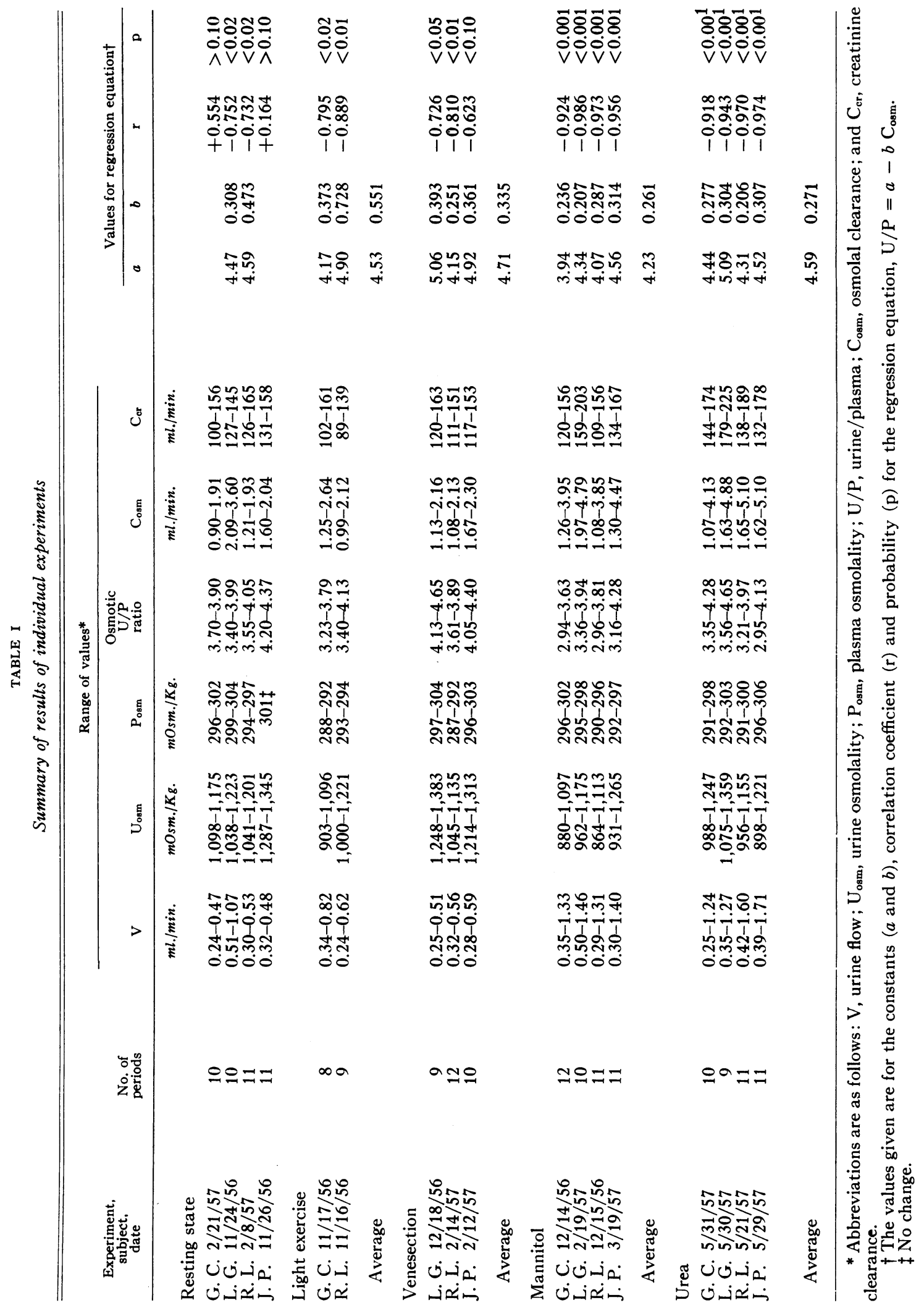


solute excretion as the osmolal clearance $\left(\mathrm{C}_{\mathrm{osm}}\right)$. The former expression is preferred to the use of urine osmolality alone since the data are thus corrected for variations in plasma osmolality. Osmolal clearance is calculated as: $\mathrm{C}_{\text {osm }}=\mathrm{U}_{\text {osm }} \mathrm{V} / \mathrm{P}_{\text {osm }}$, where $\mathrm{C}_{\text {osm }}$ and $\mathrm{P}_{\text {osm }}$ are urine and plasma osmolality and $\mathrm{V}$ is urine flow. This term is preferred to $\mathrm{L}_{\mathrm{osm}} \mathrm{V}$ alone, not only because it corrects the data for variations in $\mathrm{P}_{\text {osm }}$ but also because it would measure the volume of the isotonic fluid which, according to recent evidence (12), is delivered from the distal tubules to a concentrating site in the collecting tubules.

The statistical methods used are described by Snedecor (13). The use of correlation coefficients may be questioned since the variables used contain common terms. While certain correlations might be due in whole or in part to such a common term, the negative correlation coefficients obtained in the present study do not depend on this term.

\section{RESLLTS}

The results are summarized in Table $\mathrm{I}$ and illustrated for one subject in Figure 1. After 18 hours of water deprivation osmotic $\mathrm{U} / \mathrm{P}$ ratios ranged from 3.63 to 4.65 , urine flow was less than $0.5 \mathrm{ml}$. per minute and $\mathrm{C}_{\text {osm }}$ was 1 to $2 \mathrm{ml}$. per minute (except in Subject L.G. in whom initial values of $\mathrm{C}_{\mathrm{osm}}$ were 1.6 to $3.3 \mathrm{ml}$. per minute). The $\mathrm{U} / \mathrm{P}$ ratio and $\mathrm{C}_{\text {osm }}$ were fairly constant during the first one and one-half to two hours after waking, but subsequently a sustained increase in solute excretion was observed in the resting state in three of four experiments.

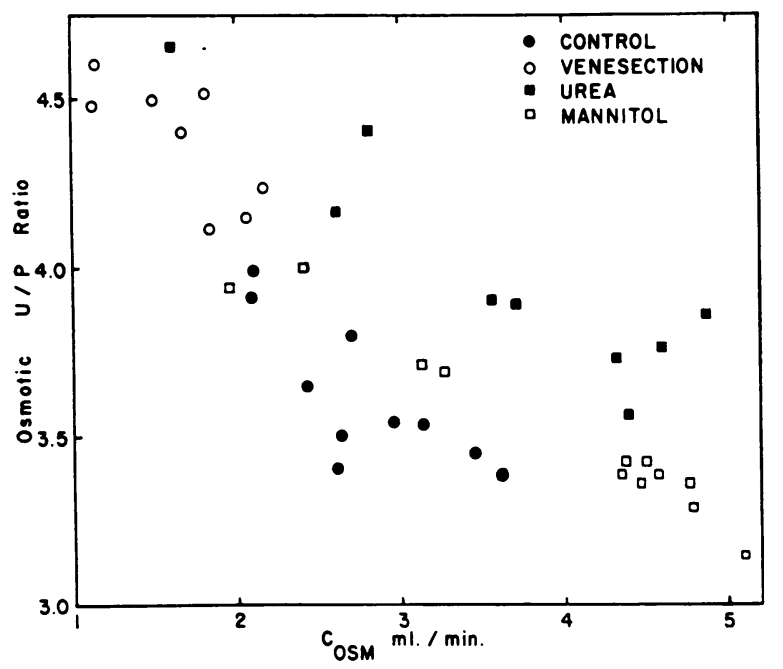

Fig. 1. Osmotic U/P Ratio vs. Osmolal Clearance (Cosm) in Subject L. G.

Each point represents a half-hour urine collection period. The closed circles ("control") are for the resting state experiment.
After venesection, $C_{\text {osm }}$ showed a distinct and persistent decrease in the experiment on Subject L.G., a small transient decrease in J.P., and an increase followed by a decrease in R.L., so that it was possible to observe the effects of a decreasing $\mathrm{C}_{\text {osm. }}$. Light exercise was followed by a sustained increase in $\mathrm{C}_{\text {osm }}$ in G.C. and by a transient increase in R.L. Mannitol and urea loading were used to increase $\mathrm{C}_{\text {osm }}$ in a predictable fashion (Figure 2). The range of $\mathrm{C}_{\text {osm }}$ for all data was 0.9 to $5.1 \mathrm{ml}$. per minute and the range of urine flow 0.24 to $1.71 \mathrm{ml}$. per minute. In most experiments, observations were made while $\mathrm{C}_{\text {osm }}$ was increasing and in this circumstance it was found that osmotic $\mathrm{U} / \mathrm{P}$ ratio decreased. After venesection (and in one light exercise experiment) observations were obtained when $\mathrm{C}_{\text {osm }}$ was decreasing and in this circumstance osmotic $\mathrm{U} / \mathrm{P}$ ratio increased. Such an inverse relationship between osmotic $\mathrm{U} / \mathrm{P}$ ratio and $\mathrm{C}_{\text {osm }}$ was observed in each experiment except the studies on Subjects G.C. and J.P. in the resting state. ${ }^{2}$ The linear regression equation, $\mathrm{U} / \mathrm{P}=a-b$ $\mathrm{C}_{\text {osm }}$, was calculated as a simple expression of this relationship. Table $I$ gives the values of $a$ and $b$, correlation coefficients ( $\mathrm{r}$ ), and probability ( $p$ ) values for the linear regression equations of each experiment. The negative correlation coefficient between osmotic $\mathrm{U} / \mathrm{P}$ ratio and $\mathrm{C}_{\text {osm }}$ was usually significant, although the constants $a$ and $b$ showed considerable variation. The value of the intercept $a$ appeared chiefly to reflect variations in osmotic $\mathrm{U} / \mathrm{P}$ ratio achieved at the beginning of the experiment. Variations in the slope $b$ on the other hand are a measure of the effect of changes in solute excretion on osmotic $U / P$ ratio. The values were between 0.206 and 0.473 , except for the light exercise experiment in Subject R.L. in whom there was a more marked decrease in osmotic $\mathrm{U} / \mathrm{P}$ ratio in association with a small increase in solute excretion $(b=0.728)$. This experiment may indicate that there is some impairment of the con-

2 The lack of inverse correlation in Subject J.P. was not unexpected since changes were so small. The control data on G.C. are unexplained. The $U / P$ ratio showed a small increase during the experiment which may have represented the effect of further dehydration, although in a previous study (14) 18 hours of water deprivation usually led to maximal osmotic $\mathrm{U} / \mathrm{P}$ ratios. 


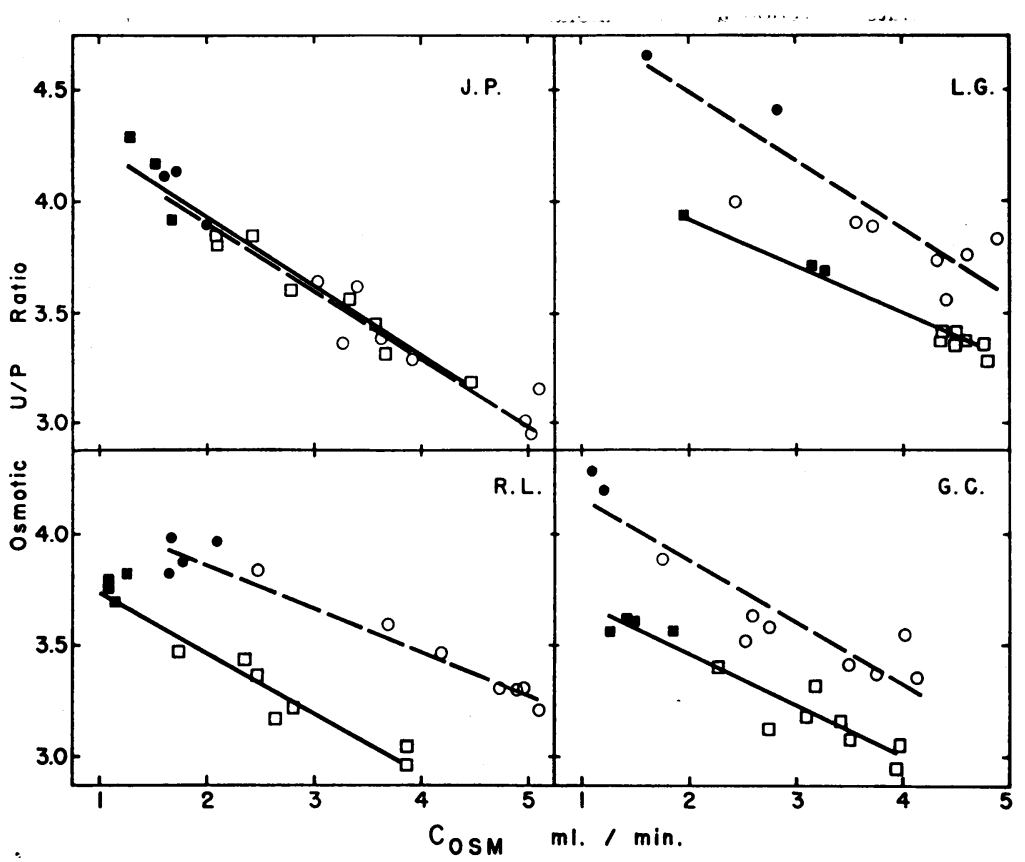

Fig. 2. Osmotic U/P vs. Cosm Before and After the Administration of Urea (Circles) and Mannitol (Squares)

Closed symbols represent the preliminary periods before loading. The regression lines for mannitol (solid) and urea (dashed) are drawn between the lowest and highest value for $\mathrm{C}_{\mathrm{osm}}$ obtained in that experiment.

centrating mechanism with light exercise such as is seen more strikingly after heavy exercise (15). The values for the slope $b$ were higher in some of the resting state, light excerise and venesection experiments than after mannitol and urea loading. The former experiments usually included a lower range of $\mathrm{C}_{\text {osm }}$ than that achieved with mannitol and urea loads and also differed in that the changes in $\mathrm{C}_{\text {osm }}$ were chiefly due to changes in $\mathrm{Na}$ and $\mathrm{K}$ excretion. Since the values

TABLE II

Total and partial correlations $(r)$ and their significance $(p)$ between osmotic urine/plasma ratio $(U / P)$, osmolal clearance $\left(C_{o s m}\right)$, and creatinine clearance $\left(C_{c r}\right)$ for each subject and for the massed data

\begin{tabular}{|c|c|c|c|c|c|c|c|}
\hline \multirow{2}{*}{$\begin{array}{l}\text { Subject, age; } \\
\text { Surface area } \\
\text { No. of periods }\end{array}$} & \multirow{2}{*}{$\begin{array}{c}\text { Type of } \\
\text { correlation }\end{array}$} & \multicolumn{2}{|c|}{ U/P vs. $C_{o s m}$} & \multicolumn{2}{|c|}{$\mathrm{U} / \mathrm{P}$ vs. $\mathrm{C}_{\mathrm{er}}$} & \multicolumn{2}{|c|}{ Cosm vs. $C_{\text {or }}$} \\
\hline & & $r$ & $\mathrm{p}$ & $\mathrm{r}$ & $\mathrm{p}$ & $r$ & p \\
\hline $\begin{array}{l}\text { G. C., } 28 \\
1.92 \\
40\end{array}$ & $\begin{array}{l}\text { Total } \\
\text { Partial }\end{array}$ & $\begin{array}{l}-0.736 \\
-0.839\end{array}$ & $\begin{array}{l}<0.001 \\
<0.001\end{array}$ & $\begin{array}{l}+0.142 \\
+0.604\end{array}$ & $<\begin{array}{c}\text { n.s. } \\
<0.001\end{array}$ & $\begin{array}{l}+0.330 \\
+0.650\end{array}$ & $\begin{array}{l}<0.05 \\
<0.001\end{array}$ \\
\hline $\begin{array}{l}\text { L. G., } 25 \\
1.96 \\
38\end{array}$ & $\begin{array}{l}\text { Total } \\
\text { Partial }\end{array}$ & $\begin{array}{l}-0.785 \\
-0.855\end{array}$ & $\begin{array}{l}<0.001 \\
<0.001\end{array}$ & $\begin{array}{l}-0.281 \\
+0.595\end{array}$ & $<\begin{array}{c}\text { n.s. } \\
<0.001\end{array}$ & $\begin{array}{l}+0.696 \\
+0.799\end{array}$ & $\begin{array}{l}<0.001 \\
<0.001\end{array}$ \\
\hline $\begin{array}{l}\text { R. L., } 24 \\
1.88 \\
54\end{array}$ & $\begin{array}{l}\text { Total } \\
\text { Partial }\end{array}$ & $\begin{array}{l}-0.743 \\
-0.753\end{array}$ & $\begin{array}{l}<0.001 \\
<0.001\end{array}$ & $\begin{array}{l}-0.315 \\
+0.360\end{array}$ & $\begin{array}{l}<0.05 \\
<0.01\end{array}$ & $\begin{array}{l}+0.667 \\
+0.680\end{array}$ & $\begin{array}{l}<0.001 \\
<0.001\end{array}$ \\
\hline $\begin{array}{l}\text { J.P., } 26 \\
1.90 \\
43\end{array}$ & $\begin{array}{l}\text { Total } \\
\text { Partial }\end{array}$ & $\begin{array}{l}-0.937 \\
-0.903\end{array}$ & $\begin{array}{l}<0.001 \\
<0.001\end{array}$ & $\begin{array}{l}-0.614 \\
-0.216\end{array}$ & $\begin{array}{c}<0.001 \\
\text { n.s. }\end{array}$ & $\begin{array}{l}+0.590 \\
+0.054\end{array}$ & $\begin{array}{c}<0.001 \\
\text { n.s. }\end{array}$ \\
\hline $\begin{array}{l}\text { All data } \\
\text { No. } \text { periods }=175\end{array}$ & $\begin{array}{l}\text { Total } \\
\text { Partial }\end{array}$ & $\begin{array}{l}-0.635 \\
-0.737\end{array}$ & $\begin{array}{l}<0.001 \\
<0.001\end{array}$ & $\begin{array}{r}-0.100 \\
+0.493\end{array}$ & $\begin{array}{c}\text { n.s. } \\
<0.001\end{array}$ & $\begin{array}{l}+0.625 \\
+0.731\end{array}$ & $\begin{array}{l}<0.001 \\
<0.001\end{array}$ \\
\hline
\end{tabular}


for $\mathrm{C}_{\text {osm }}$ were similar in the mannitol and urea experiments, direct comparison is possible (Figure 2). The slopes of the regression line are nearly identical in the two series although osmotic $U / P$ ratios were higher in the urea experiments in three of four subjects. In these instances, higher osmotic $U / P$ ratios were observed in the preliminary periods before loading was begun.

There was no striking effect of variations in creatinine clearance $\left(\mathrm{C}_{\mathrm{er}}\right)$ in the present studies. There was a positive correlation between $\mathrm{C}_{\text {er }}$ and $\mathrm{C}_{\text {osm }}$ in each subject but there was no consistent pattern of total correlation between $\mathrm{C}_{\mathrm{cr}}$ and osmotic $U / P$ ratio (Table II). When the effect of $\mathrm{C}_{\text {osm }}$ on osmotic $U / P$ ratio was eliminated by determining the coefficient of partial correlation, ${ }^{3}$ a significant positive partial correlation between $C_{\text {er }}$ and $U / P$ ratio was found in three subjects. In the fourth (J.P.) the total correlation was significantly negative and the partial correlation was not significant.

Changes in plasma osmolality were small and variable, except for the consistent increase after urea loading. There was no significant correlation between the changes in plasma osmolality and the changes in osmotic $U / P$ ratio in any group of experiments.

\section{DISCUSSION}

The acute changes in osmotic $U / P$ ratio observed in the present study are considered to be a characteristic of the intrinsic response of the renal concentrating mechanism to small changes in solute excretion and not due to influence of extrinsic factors which might alter concentrating ability. Such extrinsic factors include a change in the production of antidiuretic hormone $(\mathrm{ADH})$, variations in the prior state of hydration and variations in the prior protein intake. There is little reason to suppose that $\mathrm{ADH}$ production should decrease in the present experiments since dehydration was not relieved. In previous studies (14) the administration of vasopressin did

8 The coefficient of partial correlation is a convenient measure of the significance of association between two independent variables when one or more other known variables are held constant. Methods of correlation analysis rather than of multiple regression analysis were used since it could not be predetermined which of the variables was dependent. not increase osmotic $U / P$ ratio in subjects deprived of water for 18 hours; in fact, there was usually a decrease in osmotic $U / P$ ratio after vasopressin, associated with an increase in solute excretion. Prior water loading or water deprivation (16-18) has been shown to influence the concentrating capacity despite the administration of "maximal" amounts of exogenous vasopressin. This observation has been taken to indicate that the concentrating mechanism can be influenced by the duration or degree of dehydration through the operation of some factor other than the amount of $\mathrm{ADH}$ immediately available. Such a factor might be directly related to the effective osmolality or inversely related to the volume of the body fluids. The present study did not test these possibilities, since most changes in osmotic $U / P$ ratio occurred when both effective osmolality and extracellular fluid volume were nearly constant.

Although variations in protein or urea intake have been shown to alter concentrating ability (19) these changes were not observed in acute experiments. Small urea loads did not alter urine osmolality in the subjects of Epstein, Kleeman, Pursel and Hendrikx (19) who were on a low protein diet. It is possible that the decrease in $U / P$ ratio which accompanies an increase in solute excretion was obscured by an effect of urea itself in subjects on a restricted protein intake. In the present study, U/P ratios were higher after urea loading than after mannitol loading in three of four experiments. However, this difference was associated with higher osmotic $U / P$ ratios in the preliminary periods before the load was actually administered. Such variations in the osmotic U/P ratio after 18 hours of water deprivation have been previously observed (14) and cannot be related either to variations in solute excretion or plasma osmolality. The series of urea experiments was done in May after the other experiments of the present study had been completed so that adaptation or seasonal variation might have affected the response to 18 hours of water deprivation. With acute changes in solute excretion in an individual experiment an inverse relationship between osmotic $U / P$ ratio and osmolal clearance was observed whether the change in solute excretion was chiefly of electrolytes, urea or mannitol. Thus the present data 
confirm those previous studies $(3,4)$ which indicate that the concentrating mechanism operates independently of the contemporaneous pattern of solute reabsorption and excretion, presumably because the urine is concentrated at a site impermeable to solutes.

The decrease in osmotic $\mathrm{U} / \mathrm{P}$ ratio as $\mathrm{C}_{\text {osm }}$ increases over the range of 1 to $5 \mathrm{ml}$. per minute has been presented as a linear regression because this expression was appropriate for most experiments. However, in some experiments (G.C., mannitol; L.G, control) the slope was somewhat steeper over a lower range of $\mathrm{C}_{\mathrm{osm}}$, suggesting a curvilinear relationship. Moreover when $\mathrm{C}_{\text {osm }}$ is increased progressively above 5 $\mathrm{ml}$. per minute the relationship between osmotic $\mathrm{U} / \mathrm{P}$ ratio and $\mathrm{C}_{\mathrm{osm}}$ is clearly curvilinear (4) and $U / P$ ratio appears to approach one as an asymptote. Attempts to extend the observations on the relationship between $\mathrm{C}_{\text {osm }}$ and osmotic $\mathrm{U} / \mathrm{P}$ ratio to very low rates of solute excretion have thus far been unsuccessful. Such low rates can be achieved in chronic experiments by restricting dietary protein or in acute experiments after heavy exercise. Both procedures lead to lowering of the osmotic $\mathrm{U} / \mathrm{P}$ ratio in hydropenic men $(15,19)$. This change is taken to indicate impairment of the concentrating mechanism rather than an effect of low solute excretion itself, since under these circumstances concentrating ability (as measured by net water reabsorption) is also impaired during osmotic diuresis.

The concept that the concentrating mechanism is limited by a maximum osmotic $U / P$ ratio at low rates of solute excretion and a maximum net water reabsorption $\left(\mathrm{T}_{\mathrm{m}} \mathrm{cH}_{2} \mathrm{O}\right)$ at high rates of solute excretion and urine flow has been presented by Smith and co-workers $(6,7)$. This concept implies that there should be an appreciable range of solute excretion over which $U / P$ ratio is constant. Boyarsky and Smith (7) reported that in their hospitalized patients (age, 24 to 74 years) who had no history of renal disease, the maximal osmotic $\mathrm{U} / \mathrm{P}$ ratios after 12 to 14 hours of water deprivation were 2.2 to 3.4 and were constant up to an average urine flow of about $1 \mathrm{ml}$. per minute. There are several possible explanations for the differences between these data and the present observations. The shorter period of prior de- hydration, the older age group, and possibly a poor prior protein intake may have led to the lower initial osmotic U/P ratios in Boyarsky and Smith's subjects. Moreover the conclusion that osmotic $U / P$ ratio was constant at urine flows below $1 \mathrm{ml}$. per minute appears to be based on preliminary collection periods which show little variation in urine flow in most subjects.

The striking inverse relationship between osmotic $U / P$ ratio and osmolal clearance obtained in the present study makes it difficult to assess the effect of other variables. While a positive partial correlation between osmotic $U / P$ ratio and creatinine clearance was obtained in three of our subjects, the techniques used are too inaccurate to determine the effect of changes in glomerular filtration rate on concentrating ability. On the other hand, a marked decrease in glomerular filtration rate with heavy exercise (15) or constriction of the renal artery (20) is associated with definite impairment of concentrating ability.

\section{SUM MARY}

The effect of small changes in osmolal clearance on the osmotic urine/plasma ratio achieved after 18 hours of water deprivation has been studied in healthy men. Changes in osmolal clearance over the range of 0.9 to $5.1 \mathrm{ml}$. per minute and in urine flow over the range of 0.24 to $1.71 \mathrm{ml}$. per minute were observed in the resting state, after venesection, after light exercise and during mannitol and urea loading. The osmotic urine/plasma ratio was not constant. There was a significant inverse relationship between osmotic urine/plasma ratio and osmolal clearance at low rates of solute excretion and urine flow.

\section{ACKNOWLEDGMENT}

We wish to express our appreciation to Miss Patricia A. Maley for her technical assistance and to the medical students who served as subjects for these experiments.

\section{REFERENCES}

1. Smith, H. W. Principles of Renal Physiology. New York, Oxford University Press, 1956, pp. 122 ff.

2. McCance, R. A. The excretion of urea, salts, and water during periods of hydropaenia in man. $\mathrm{J}$. Physiol. (Lond.) 1945, 104, 196. 
3. Hervey, G. R., McCance, R. A., and Taylor, R. G. O. Forced diuresis during hydropenia. Nature (Lond.) 1946, 157, 338.

4. Rapoport, S., Brodsky, W. A., West, C. D., and Mackler, B. Urinary flow and excretion of solutes during osmotic diuresis in hydropenic man. Amer. J. Physiol. 1949, 156, 433.

5. Wesson, L. G., Jr., and Anslow, W. P., Jr. Effect of osmotic and mercurial diuresis on simultaneous water diuresis. Amer. J. Physiol. 1952, 170, 255.

6. Zak, G. A., Brun, C., and Smith, H. W. The mechanism of formation of osmotically concentrated urine during the antidiuretic state. J. clin. Invest. 1954, 33, 1064.

7. Boyarsky, S., and Smith, H. W. Renal concentrating operation at low urine flows. J. Urol. (Baltimore) 1957, 78, 511.

8. Bonsnes, R. W., and Taussky, H. H. On colorimetric determination of creatinine by Jaffe reaction. $\mathrm{J}$. biol. Chem. 1945, 158, 581.

9. Hare, R. S. Endogenous creatinine in serum and urine. Proc. Soc. exp. Biol. (N. Y.) 1950, 74, 148.

10. Van Slyke, D. D., and Cullen, G. E. The determination of urea by the urease method. J. biol. Chem. 1916, 24, 117.

11. MacFadyen, D. A. Estimation of formaldehyde in biological mixtures. J. biol. Chem. 1945, 158, 107.

12. Wirz, H. The location of antidiuretic action in the mammalian kidney in The Neurohypophysis, Proceedings of the Eighth Symposium of the Colston
Research Society, H. Heller, Ed. New York, Academic Press, 1957, pp. 157 ff.

13. Snedecor, G. W. Statistical Methods, 5th ed. Ames, Iowa, Iowa State College Press, 1956, p. 534.

14. Raisz, L. G., McNeely, W. F., and Saxon, L. G. Studies on the renal concentrating mechanism. I. Effect of vasopressin. J. Lab. clin. Med. 1958, 58, 437.

15. Raisz, L. G., Au, W. Y. W., and Scheer, R. L. Studies on the renal concentrating mechanism. III. Effect of exercise. J. clin. Invest. 1959, 38, 000.

16. West, C. D., Traeger, J., and Kaplan, S. A. A comparison of the relative effectiveness of hydropenia and of Pitressin in producing a concentrated urine. J. clin. Invest. 1955, 34, 887.

17. Jones, R. V. H., and de Wardener, H. E. Urine concentration after fluid deprivation or Pitressin Tannate in Oil. Brit. med. J. 1956, 1, 271.

18. Epstein, F. H., Kleeman, C. R., and Hendrikx, A. The influence of bodily hydration on the renal concentrating process. J. clin. Invest. 1957, 36, 629.

19. Epstein, F. H., Kleeman, C. R., Pursel, S., and Hendrikx, A. The effect of feeding protein and urea on the renal concentrating process. J. clin. Invest. 1957, 36, 635.

20. Berliner, R. W., Levinsky, N. G., Davidson, D. G., and Eden, $M$. Dilution and concentration of the urine and the action of antidiuretic hormone. Amer. J. Med. 1958, 24, 730.

\section{SPECIAL NOTICE TO SUBSCRIBERS}

Post Offices will no longer forward the Journal when you move.

Please notify The Journal of Clinical Investigation, Business

Office, 333 Cedar Street, New Haven 11, Conn., at once when you have a change of address, and do not omit the zone number if there is one. 